intensity of the radio flux received being recorded continuously for each elevation of the beam for about $100-200 \mathrm{hr}$. Of ninety records obtained, twenty were spoiled by the effects of rain during August and September 1950, and fifty of the remaining records showed the existence of a localized source of radio frequency at right ascension $00 \mathrm{~h} .40 \mathrm{~m}$.

The results afford conclusive evidence that the observed source lies close to the centre of $M 31$, the right ascension being that given above and the declination N. $41^{\circ}$, Epoch 1950, and the apparent dimensions of the source are consistent with a source of radio frequency comparable with the main body of $M 31$. It is most improbable that the finite width of the source is due to a coincidence of two point sources. A comparison of the measured intensity of the emission with that to be expected if $M 31$ is similar to the galaxy is made on the assumption that the mass of $M 31$ lies between $3 \times 10^{10}$ and $10^{11}$ solar masses compared with $10^{11-2} \times 10^{11}$ for the galaxy, and on such assumption the intensity of the radio frequency from $M 31$ would be expected to lie between $10^{-24}$ and $7 \times 10^{-24}$ W. m..$^{-2}(\mathrm{c} . / \mathrm{s} .)^{-1}$, which include the observed values. The agreement suggests that M31 possesses similar characteristics to the galaxy as far as radio-frequency emission is concerned.

\section{THE ATLANTIDE EXPEDITION}

IN June 1945 the Danish sculptor, Mr. Viggo Jarl, wrote to the University of Copenhagen to place his three-masted auxiliary motor-yacht Atlantide at the disposal of the University for a scientific expedition lasting up to ten months. Mr. Jarl not only undertook to finance the running of the ship but also allocated a sum of $10,000 \mathrm{kr}$. towards the scientific equipment.

Following this generous offer, plans were drawn up for an expedition off the coasts of tropical West Africa under the leadership of Dr. A. F. Bruun, of the Zoological Museum, University of Copenhagen, who was to have as colleagues two young zoologists, Mr. Jørgen Knudsen and Mr. Torben Wolff. Furthermore, when Prof. A. V. Hill, then secretary of the Royal Society, was on a visit to Copenhagen in June 1945, the plans for the expedition were widened. Prof. R. Spärck, head of the Zoology Department, proposed to Prof. Hill that the British Museum (Natural History) should be invited to collaborate in the work of the expedition. As a result, Dr. F. C. Fraser joined Mr. Jarl and the Danish scientists as the representative of the Museum.

The Atlantide sailed from Copenhagen on October 3 , 1945, and returned on June 17, 1946. During her time at sea, 170 stations were worked, mainly between the Canary and Cape Verde islands, off French Guinea, Sierra Leone, Liberia, the Ivory and Gold Coasts, Nigeria, French Equatorial Africa, the Belgian Congo, Angola, Gambia and Senegal. The gear used for collecting the benthic organisms included otter and Agassiz trawls and various dredges, while Van Veen and Petersen grabs were used for bottom samples. Hauls for plankton and neckton were made with one-metre and two-metre stramin nets and a Nansen standard plankton net. In addition, hydrographic observations were made off the Gold Coast and Nigeria.

* Atlantide Reports: Scientific Results of the Danish Expedition to the Coasts of Tropical West Africa, 1945-1946. Report No. 1. Pp. $247+16$ plates. $35 \mathrm{kr}$. Report No. 2 . Pp. $303+2$ plates. $40 \mathrm{kr}$. (Copenhagen: Danish Science Press, Itd., 1950-1951.)
It is at once evident from Dr. Bruun's introductory report that the Atlantide Expedition was efficiently organized. At least three hundred species of fishes. were taken, which is well over half the number known off the African coasts from Gibraltar to Cape Town. When this collection of fishes has been reported on, it must not only add to knowledge of the distribution and biology of the West African fauna but should also be of value to fisheries biologists at work in this area.

During the Expedition, attempts were made to harpoon the very elusive Delphinidæ, and eventually one was taken. This proved to be a male of the littleknown species Stenella frontalis (Cuvier) and it is described by F. C. Fraser in Atlantide Report No. 1. The close comparative study of this dolphin in relation to other members of the genus has shown very clearly that the systematics will not be satisfactorily appreciated until a much larger series of individuals is at hand, together with observations on sex and the external and internal anatomy.

The anatomy of the urinogenital tract in this dolphin is described by L. Harrison Matthews. While the relationships of these organs in the Odontoceti show a general degree of conformity, Matthews clearly traces the resemblances of the male urinogenital tract of Stenella to that of other dolphins. Although this might have been expected, the paper shows that there are most interesting problems in the comparative anatomy of the urinogenital tract of the Cetacea. awaiting further study.

A paper by Jørgen Knudsen on the egg capsules. and development of the prosobranch molluses has. the freshness of approach which we have come to. expect from the Danish biologists working on the reproductive larval ecology of invertebrates. Of the thirty-two species examined, twenty-two were found to have a non-pelagic development, whereas the remainder had a pelagic phase. 'This high proportion of species without pelagic larvæ is more like that found in colder waters than in the tropics, where species with pelagic larvæ are usually predominant. Knudsen suggests that this may be correlated with two environmental factors: first, the system of currents which would tend to carry planktonic larvæ away from settling areas, and secondly, the 'poor supply of planktonic food occasioned by the low nutrient-salt content of the Guinea Current.

Finally, in Atlantide Report No. 1, there are papers by Torben Wolff on the bird collection, by Bengt Hubendick on geographical variation in Siphonaria pectinata (L.), and by F. Jensenius Madsen on the Asteroidea. From a statistical study of shell characters, Hubendick finds a cline in the number of radii in the sculpture and in the pattern of the shell, and points out that this appears to be the first account of such variation in marine invertebrates. Madsen's well-illustrated systematic account of the starfishes contains descriptions of two new species of Astropecten and one new species of Luidia.

In Atlantide Report No. 2, the Echinoidea are reported on by Th. Mortensen, who describes a new species of Brissopsis nearly allied to the West Indian $B$. elongata, a further indication of the close relationship between the African and West Indian echinoids. The greater part of the report is taken up with papers by L. B. Holthuis on the caridean Crustacea and by D. M. Reid on the gammarid and caprellid Amphipoda.

The large collection of Caridea contains more than half the number of known species from tropical West African waters, many being represented by a good 
size of individuals. Fifteen new species are described, and there are thirty-one new records. From this work Holthuis concludes that present knowledge of the distribution of most Caridea ". . . does not allow any definite conclusions to be drawn from the available data, other than stating the close relationship with the European and East American faunas and the much less clear affinity to the Indo-West Pacific Caridea".

Quite similarly, Reid finds that the extensive collection of amphipods comprises a great many species originally described from the European seas and the Mediterranean. In fact, comparatively few southern forms were taken, suggesting a dominant influence of the prevailing south-going current system. Twenty-four new species have been proposed and the collection contains forty-eight species not previously known from tropical West African waters. There is also a section on the problem of intersexes in the Gammaridea, and an appendix giving a list of the West African Gammaridea and their distribution which will be welcomed by specialists in this difficult group.

In conclusion, it should be recorded that the imaginative and generous interest shown by Mr. Jarl not only made possible a resumption of oceanographical work immediately after the War, but was also a great stimulus to Danish marine biologists after several years of isolation. The results so far published amply bear out the latter, and it is to be hoped that further Atlantide Reports will soon be ready. The publication of this well-produced series is being made possible by grants from Mr. Jarl and the British Museum (Natural History).

\section{N. B. Marshall}

\section{FUNDAMENTAL EDUCATION}

$\mathrm{S}^{\mathrm{I}}$

INCE its foundation, Unesco has considered the $O$ problems arising out of illiteracy to be its major challenge and has developed programmes of "fundamental education" to help the $1,200,000,000$ men and women in the world who can neither read nor writé.

The main purpose of fundamental education is to help people understand their immediate problems and to give them the skills to solve them through their own efforts. It is an emergency solution designed to help masses of illiterate adults and children in countries the educational facilities of which have been inadequate.

Until 1950, Unesco's fundamental education work, because of a limited budget, was experimental. The experiments, however, repeatedly produced the same conclusions, no matter where they were conducted. Fundamental education cannot hope to achieve tangible results without men and materials, that is, without qualified workers and effective educational materials specifically designed for its task.

Neither, at present, is available. The demand for primers in Creole or agricultural manuals in Sesuto is not great enough to attract private capital to the long job of research required to produce them. Teacher-training schools ordinarily do not require their graduates to be able to teach reading in one class and contour farming in the next.

If each individual country were to attempt this job, the overall cost would be enormous, and an inevitable waste of money and man-power would result. The experiments showed that a pooling of resources at regional levels is needed.

Unesco has now put forward a plan to aid its member States by helping to train fundamental education workers and by developing samples of the teaching materials they need. This plan is intended to operate as a twelve-year programme in which a world network of six production and training centres will be established in five regions, namely, Latin America, Equatorial Africa, the Middle East, India and the Far East (where two centres will be set up). The plan was approved by the unanimous vote of the sixty-four member States of Unesco at the sixth session of the Unesco General Conference, which met in Paris during June-July 1951.

The goal of this programme is to train some five thousand fundamental education specialists. These graduates, in turn, will staff similar training centres organized on national and local lines. It is these latter centres which will train the teachers who will work in the field.

Under Unesco's plan, each centre will be equipped to handle yearly two classes of a hundred students each. These students will be selected by their Governments and sent to the centre in their region not as individuals but as teams. A typical team studying at a centre might include an adult educator, a sanitary engineer, a nurse, a rural school teacher and an agricultural expert.

Some of the students at the centre will have been already trained in their own specialities under the guidance of three other United Nations agencies the Food and Agriculture Organization, the International Labour Organization and the World Health Organization. They will come to the Unesco centres to learn how to put their technical knowledge to work in underdeveloped regions through fundamental education techniques.

The course of study planned for these students will cover twenty-one months. At first, there will be an intensive nine-month training period and then, after a one-month vacation, two months of "on-thejob training" at institutions conducting fundamental education work. The course will conclude with five months of practical field.work as teams in the vicinity of the centres, one month of vacation and a threemonth refresher course at the centre.

A typical centre in operation will be organized to perform a four-fold task; namely, research, production of educational materials, teacher training, and aid to fundamental education activities in its region.

These functions will be carried out by three departments. The first, in charge of research, will determine the specific needs of the region in which the centre operates and the methods required to meet them. The second, or production department, will be responsible for developing sample text-books, films, film-strips, wall-charts and other materials needed in fundamental education. One of the five centres will be equipped with a complete production crew to turn out films and other visual materials. Another will be similarly staffed for radio work, with an experimental recording studio included in its equipment.

The teaching faculty of the centre will comprise the third or training department. Staff will be made up of instructors in sanitation, hygiene, agriculture, handicraft industries, home economics and literacy training, as well as general fundamental education specialists. 